\title{
Twin Archetype in Louise Erdrich's Novels
}

\author{
Xiaoli Huang ${ }^{1, *}$ \\ ${ }^{1}$ School of Foreign Languages and Literature, Yunnan Normal University, Kunming, Yunnan 650500, China \\ *Corresponding author. Email: 23022537@qq.com
}

\begin{abstract}
Twin stories are central to American Indian mythology. Native American novelist Louise Erdrich has created the images of twins in several of her works. Taking the mythic twins Matchkwewis and Oshkikwe from the Anishinaabe tales and stories as an archetype, many of Erdrich's novels, such as Tracks, Love Medicine, The Antelope Wife, and The Round House, are based on the stories of twins and depict different twins or twinlike characters. Erdrich takes up the responsibility of storyteller to tell stories about residents on the reservation, carrying forward Indian culture and conveying positive value to the readers. From the perspective of the twin archetype, this essay discusses the power of action of these twin characters in Erdrich's novels, so as to interpret her replacement strategy of folk tales.
\end{abstract}

Keywords: twins, myth, archetype, replacement, storyteller

\section{INTRODUCTION}

Louise Erdrich (1954- ) is the most popular, most award-winning, and most prolific Native American writer. Her novels set in North Dakota, telling the century-old tales of the people on the Indian Reservation. Erdrich is good at constructing complex relationships between her characters. Inspired by Indian mythology, she has created twins with very different personalities.

The story of twins is an important part of American mythology. The sacred book of the Maya of High Kiche, Popol Vuh, contains a creation myth followed by mythological stories of two heroic twins: Hunahpu and Xbalanque (Jones 150). They participated in the creation myth and ushered in a new era. In American Indian oral culture, there are also many legends of twin heroes.

Twins archetypes are common in literature. Nooy defines twins in literature as "a vexing issue given that almost any relation of resemblance and/or opposition may be used to identify a double"(10). In Erdrich's fiction, twin stories display similar features: resemblance and/or opposite.

The twin sisters Matchikwewis and Oshkikwe,

*Funds: Yunnan Province Philosophy and Social Science Planning Project "A Study on mythological Archetypes and Ethnic Identity in Louise Erdrich's Novels"(HX2019082770); The university-level general project of Yunnan Normal University, "A Study on The Literary Image of American Frontier Cultural Landscape - A Case Study of Erdrich's Novels"(2019BSXM21). two mythological figures of the Indians, appear many times in Erdrich's fiction. They are the daughters of Nanabozho, a tribal hero and trickster. The twins, considered sacred, provide a spiritual guide to the virtues of tribal women. The older sister Matchikwewis is curious, impulsive and charming, symbolizing the dark side of the character. On the contrary, the younger sister Oshkikwe is reserved, quiet and pragmatic, representing good character (Jacob 115-116). ${ }^{1}$

How do contemporary novelists make good use of those mythical and legendary figures in their novels? The clue of literary development and evolution lies in the "displacement" of the archetype. According to Ye, "The whole literature from myth to realism is based on a common structural principle - "myth - legend - realism" (13). Erdrich borrows and develops twin images from American Indian mythology and constructs a "displacement" in her own fiction. From the perspective of mythological archetype, this essay analyzes Erdrich's replacement of Indian mythology and its effects. In Anatomy of Criticism, Frye divides literary works into five modes based on the hero's power of action: myth, romance, high mimetic, low mimetic, and ironic (Frye 33-35). These characteristics correspond to four modes

\footnotetext{
Oshki means "young, unmarried," and "Oshkikwe" means a young woman in the native language, who has the traditional virtues of a woman. Matchikwewis, as opposed to Oshkikwe, is an older, greedy woman with a strong desire. According to some legends, the sisters were not twins, and Matchikwewis was one year older than Oshkikwe.
} 
according to the power of the twin image in the novels.

\section{ROMANCE: TWINS FROM TRACKS}

Sarve-Gorham, when analyzing the twin themes in Tracks and Love Medicine, points out that in American Indian culture, the female characters of the twins are common. He believes that Fleur and Pauline were derived and distinct from the twin characters in Indian mythology. The two women are not related by blood, and their twin-relationship is manifested in supernatural forces and religious beliefs (Sarve-Gorham 167-190).

Paula Gunn Allen emphasizes that the twinned concept of the American Indian spiritual tradition is distinctive. He points out "in some regards, Matchikwewis and Oshkikwe are archetypes, who in their sisterhood and powers resemble such pairs among the Pueblo, the Navajo, the Aztec..."(Allen 140). The twin-archetype in Tracks is Fleur and Pauline, both of who follow the romance mode, while differing from each other greatly. Their power of actions is higher than that of ordinary people, and they can transcend the laws of nature. Through the portrayal of the twins, Erdrich shows the endless charms of Indian culture, and injects vitality into this ancient form of storytelling.

If superior in degree to other men and to his environment, the hero is the typical hero of romance, whose actions are marvelous but who is himself identified as a human being. The hero of romance moves in a world in which the ordinary laws of nature are slightly suspended: prodigies of courage and endurance, unnatural to us, are natural to him, and enchanted weapons, talking animals, terrifying ogres and witches, and talismans of miraculous power violate no rule of probability once the postulates of romance have been established.(Frye 33)

There are two distinct lines in Tracks (1988), which unfold as a first-person "I," narrated alternately by Nanapush and Pauline. To assuage Lulu's resentment of her mother and persuade her to give up marrying a family feud, Nanapush tells Lulu the story of Fleur. In order to cover up her despicable acts, Pauline tells her story with Fleur. The two narrators have clearly directed intentions, and the interwoven narrative lines weave the legend of the reservation together.

Fleur comes from a Shamanic lineage, and the people are in awe of the Pillager family. Because Medicine man has healing powers and is also a harmful form of witchcraft. Fleur believed in the primitive religion of the Indians. According to Animism, all animals and plants are alive, including wild animals, mountains, even a leaf and a stone. Shamans can communicate with spirits and spirits of all sizes in nature, and have their own animal or plant eudemon.

Bear is the symbol of the Pillager's totem. When Fleur gave birth to Lulu, a mysterious bear came into the house, bringing her strength to give birth smoothly. Fleur is able to use witchcraft to accomplish things that ordinary people cannot do, becoming more mysterious. Not only that, Fleur also has a mysterious connection with the mysterious lake monster. "Man stayed out of Fleur Pillager after the second drowning. Even though she is good-looking, nobody dared to court her because it's clear that Misshepezhu, the water man, the monster, wanted her for himself"(Erdrich 1988:11). Misshepezhu appears in the lake only after the Pillager family has arrived on the reservation and is considered their eudemon. Although Fleur can't swim, she survives after she fell into the water several times.

Pauline, from the Puyat family, is in the opposite situation. Their ancestry is a mix of aboriginal and Canadian, and they are notorious for cheating and being disliked by local people. She and Fleur used to work in Argus, a small white town. Pauline "was so poor-looking and was invisible to most customers and to the men in the shop" (Erdrich 1988:15). Pauline is hot-tempered and competitive. Jealous of the intimate relationship between Eli and Fleur, she gives Eli an aphrodisiac potion with another woman, causing this couple's breakup. She is also cold and aloof with her relatives. Diseases brought by European settlers led to the death of many aborigines. Pauline never cares about the life and death of her family, because she hates her native blood. She slept with alcoholic Napoleon Morrissey and became pregnant After giving birth to a baby who is adopted by Bernard, she flees to a convent. Pauline chooses to believe in the opposite of Fleur and decides to convert to Christianity. She refuses to enjoy physical comfort and happiness.

The personality, appearance, experience and beliefs of Fleur and Pauline are entirely different. But the bonds between them are inextricably linked. Like them, their offspring appear to be linked by a dense web. Their daughters fall in love with the same man, Nector. The stories of Fleur and Pauline have been romanticized and mythologized, their behavioral power is to some extent outstanding. They wear amulets of strange powers and possess supernatural powers. With her extraordinary ability and courage, Fleur became a tribal legend, and Pauline created a sacred monument that was admired by men and women. 


\section{THE HIGH MIMETIC MODE: TWINS FROM LOVE MEDICINE}

Judging from creation time, Fleur and Pauline aren't Erdrich's original twins - their daughters Lulu and Marie are the first twin sisters, but they present high mimetic in terms of their power of action.

Barnouw edited and published a collection of Chippewa Myths and Legends in Wisconsin in 1977, which collected the folktales and legends of the Chippewa and had certain reference value in academic and cultural dissemination. Among them, the story of Matchikweis and Oshkikwe involves the moral code, marriage and love view, mate selection standards and other aspects of the Matchikweis - Oshkikwe sisters. These stories are often told by tribal women and set an example for young women. "Matchikweis, is supposed to be the more foolish and impulsive, while the younger one, Oshkikwe, is often represented as having more common sense and prudence. Stories about these two sisters were told by women. They sometimes served a cautionary purpose, showing what sort of behavior should be avoided by young girls"(Barnouw 93).

The first story, "Bebukowe the Hunchback," is about the twin sisters, who have found a body. Oshkikwe's psychic powers told her that the body was not as ugly and hunchbacked as it looked, but that there was a handsome young man hidden inside. Oshkikwe used hair oil to call back the man's life and restore his appearance. The crafty Matchikweis stood by and when he saw the restored man he immediately announced, "He will be our husband." Oshkikwe simply replied, "No, he will be our brother." The young man killed many turkeys to express his love for Oshkikwe and eventually married her (Barnouw 95).

In the second story, "The Star Husband," the two sisters always competed with each other. Once the two of them slept out in the open, Matchikweis thinks that the brightest star in the night sky was a young man and the faintest was an old man. She longed for the shining star, but Oshkikwe said she did not care, preferring the dark one. Instead, Oshkikwe was favored by the young, and Matchikweis had to stay with the old man (Barnouw 103).

Like fairy tales, the stories of Matchikweis and Oshkikwe serve as a cautionary story-a warning to future generations on how to survive. For women, marriage is undoubtedly the biggest issue they face in community life. On closer examination, the characters in Love Medicine $(1984,1993)$ overlap much with the two stories.
Like Matchikweis, Lulu is impulsive, headstrong and sexy. She does not shy away from the desire to chase sex, bold and arbitrary. She gives birth to eight sons of different fathers. Lulu and Nector go to the same boarding school and have a crush on each other. Later Nector falls in love with the innocent Mary and plans to marry her. Young Lulu huffs into the arms of her uncle, a legendary figure, Moses Pillarger, and bears his child. Lulu often wears short skirts and high heels, and, even in her late sixties, still has rosy lips and bright fingers (Erdrich 1993:305).

Mary, younger than Lulu, is endowed with the virtues of Oshkikwe. She is virtuous and wellbehaved. Mary adopts the tribe's orphans or abandoned children and works hard for her family. It is Mary who dragged the alcoholic Nector out of his cellar and encourages him to run for tribal chief. It can be said that Nector's success is almost entirely due to Mary. In "Bebukowe the Hunchback", Oshkikwe casts spells to restore the young man's appearance; Mary also tries to turn the temporarily disfigured man into a tribal leader. The "handsome and distinguished man"(Erdrich 1993:277) catches Lulu's eye again. To escape the responsibilities of the family, Nector secretly hangs out with Lulu. Their illegitimate son, Lyman, is born. Nector's older brother Eli often gives Mary money to support the family and takes care of the children instead of his younger brother. Mary is grateful, but represses her feelings and keeps to her duty. Sexy, amorous Lulu and introverted, virtuous Marie are in line with the "MatchikweisOshkikwe" story in the sister character setup.

The young man gives turkeys to the sister and they settle for life in "Bebukowe the Hunchback"; while in Love Medicine the couple is settled for life on a wild goose brought back from a hunt by Nector. Mary and Nectort get married in the prime of their lives; while Moses is nearly twenty years older than Lulu².

As Frye points out, "He has authority, passions, and powers of expression far greater than ours, but what he does is subject both to social criticism and to the order of nature. This is the hero of the high mimetic mode (Frye 34). Both Mary and Lulu joined the American Indian movement in the 1980s, when the national consciousness of the Indians was awakened. Mary begins to speak old language after moving into an old-age home, and she "learned how uncomfortable English can sound" (Erdrich 1993:265). Lulu is passionate about the revival of Indian culture and also plays the leading role in the revival campaign, protesting against her son, Lyman, who runs a factory on the reservation. Despite their differences in character, Lulu and

\footnotetext{
Lulu's mother, Fleur Pillager, and Moses Pillage were
} Cousins. They were the only blood left in the Pillager family. 
Mary make peace after Nector's death and lead the tribe in a revival of traditional Indian culture. Although Mary and Lulu do not possess their mother's mysterious power, the spirit of leadership they display cannot be ignored. But their behaviors are still subjected to social constraints and they still judged by other people from their conduct. On this level, the action power of fictional characters is a high mimetic of mythological archetypes.

\section{THE LOW MIMETIC MODE: TWINS FROM THE ANTELOPE WIFE}

Tracks and The Love Medicine are the preliminary attempt to shape the image of the twins. The Antelope Wife presents the theme of twins more incisively and vividly. Each of the novel's four parts is punctuated by an Indian founding myth - the twin sisters competing to make the prettiest bead. "The niizhoodenhyag are very old when they decide to sew this world into being. One twin use light and the other dark. The first twin beads are cut-glass whites and pales, and the other twin beads are glittering deep red and blue-black indigo."(Erdrich 1998:1). One presents the bright side while another the dark side.

In The Antelope Wife, two sisters fall in love with the same young man. The main story dates back to the mid-19th century, when white troops slaughtered an Indian village. Scranton Roy, a trooper, killed two children and an Indian woman. In the late 19th century, the Blue Prairie Woman gave birth to twin girls. Every generation since then had a pair of girls born and named Mary and Zosie. Years later, a guilt-ridden Roy took his grandson, Augustus Roy, to the village in the hope of making amends. The second generation of twin daughters, Mary and Rosie, received them. After his grandfather died, but Roy stayed in the Indian village and fell in love with the twin sisters.

The twins wear the same clothes, have the same haircut and even behave the same way. Sometimes they appear together on Roy's way home from work, sometimes only one comes. Roy can not tell which girl he is holding by the hand or kissing. He dices and decides to marry Mary, but on their wedding night, he clearly realizes that the girl in the wedding room is Rosie. He finds himself in love with two women and pretends to know nothing about them, even when he can easily tell them apart. Because he has been trapped in the two sisters together to weave the "string of beads," unable to extricate themselves.

In fact, Rosie has a sweet tooth and Mary a sour, salty taste. Mary does not like meat or eggs. She prefers a vegetarian diet. Rosie, on the contrary, likes meat and hates vegetables. Rosie is good at taking control, while Mary pays attention to details. Rosie likes to cast nets for birds, which is very offensive to Mary. From their preferences, Rosie is like the mythical elder sister, warm, bold and fierce, while Mary is kind and delicate.

In the 1940s and 1950s, the twins' names broke off in Rozin's generation - her twin sister was Aurora, who died at age 5. Rozin named her twin daughters Kelly and Deanne, who also died unexpectedly at age 11. A name is more than just a syllable, it is endowed with spiritual power, inherited from the mother's name, is a blessing. Rozin realizes their error, and "the continuity of names was broken, and they suffered their own consequences" (Erdrich 1998:35). The name has been given a lingering meaning and has the power to protect its owner. The fate of the interrupted generation changed, and one of the twins would die. Just like those woven patterns, the change of names has broken the original balance, the pattern has changed, the fate of the characters has also changed.

"Blue with fish blood, red with ground hearts... No one knows which twin would fall asleep first, so that the other would temporarily become the dominant color, and no one knows for how long "(Erdrich 1998:71). The twin sisters in the folk tale weave a string of beads. The sleeping knitter gives the opportunity to the awake one. Like a woven string of pearls, the twin sisters in the novel are controlled by the god of creation. This arrangement gives the novel a strong mysterious color, and at the same time implies the plot direction of the novel.

The twin sisters in the wedges are creation deities who weave the destinies of ordinary people according to their preferences. The fourth wedge of the novel writes:

The woman's child swallowed a bead, and she ran after it, "she had to follow them, searching, searching out their panicked trail, calling for them in the dark places and the bright places, the indigo, the white, the unfinished details and larger meaning of her design. (Erdrich 1998:243)

The story jumps and alternates between myth and reality. The mysterious twin sisters in the novel competed with each other. The characters' fates changed as the colors of the beads changed. The relationships of the characters in the novel are also strung together like beads. The end of the story reveals that the "Blue Prairie woman" is the granddaughter of the woman Roy has killed. The relationship between the Blue Prairie Women, Roy and the Shawano family has been arranged.

The reader resonates with the protagonist's common conception of human nature, which is the low mimetic model. "If superior neither to other men nor to his environment, the hero is one of us"(Frye 34). Without the magical powers of myth 
and legend, Rozin and Kelly are ordinary Native Americans who live in the middle and late 20th century. They are typical town Indians who had moved into town and become increasingly unfamiliar with their ancestral culture. Although Kelly later moves back to the reservation and studies Indian culture, she no longer possesses any magic power as those in the folk tales or as her ancestors do.

\section{IRONY: TWINS FROM THE ROUND HOUSE}

In The Round House(2012), Erdrich iterates her portrayal of the twins story, a white brother and sister. The twin in this novel follows the ironic mode. "Irony, as a mode, is born from the low mimetic; it takes life exactly as it finds it"(Frye 39).

George, a white man, and his wife Grace open a store on the reservation. They earn money from the Indians, but embarrass the Indians in every way. After grace gives birth to twins, she viciously abandons her malformed baby girl, Linda, who is later adopted by a kind-hearted Indian couple. Years later, Grace contacts Linda out of the blue because Linda's twin brother, Linden, is dying of kidney failure, and she wants Linda to donate a kidney. Even though resentful of her birth parents, Linda donates Linden her kidney.

After the kidney transplant, Linda's life is in danger; Grace applies to become Linda's guardian in the hope of inheriting Linda's fortune. Judge Bazil Coutts dismisses the application because there is no way to prove Linda's adoptive relationship with her adoptive parents. Grace fails to become a guardian and later dies of an aneurysm.

Linden's girlfriend Mayla and the local magistrate Yeltow gives birth to an illegitimate child. When registering her child, Mayla insists on putting Yeltow's name in the father column. To cover up the truth, Yeltow orders Linden to retrieve the documents. Bazil's wife, Geraldine, works for the tribal registry office. Linden kidnaps Geraldine and Mayla. He blames Geraldine for his misfortune, rapes her and tried to burn Geraldine and Mayla.

Like the twins before them, the twins represent two sides of the same identity. Linden has a good face, but he is fierce and greedy. Linda thought Linden and her mother are as insatiable as Wiindigoo $^{3}$. While in the womb, her brother begins robbing her of nourishment, leading to her deformity. Instead of getting better, Linden gets worse after his recovery, and Wiindigoo's true nature is revealed. Linda has an ugly face but a kind

Wiindigoo is an ogre in Indian legend. Humans possessed by evil spirits can turn into cannibals with human or monster characteristics, cannibalism in the face of danger. heart. Knowing that judge Bazil Coutts' family is using her to catch the criminal — his brother; instead of resenting them, she helps Joe destroy the evidence of the killing. She is kind and willing to do anything for the family to make up for her brother's mistakes.

Unlike previous twin stories, Linden and Linda's story is more quotidian and real. The creation motivation for The Round House comes from the fact that there are frequent rape cases of indigenous women on the reservation. Erdrich writes in the afterword to this novel, one in three Native American women has been raped, not including unreported cases. More than $86 \%$ of rapists were not Indian (Erdrich 2012:319). Erdrich gradually shifts her gaze from legend to reality and politics. Modern literature, as Frye puts it, is in an age when heroes are dead, and anti-heroes are the small, powerless people who play the leading role in a strange, lonely world. These anti-heroes have echoes of mythic and epic heroes of the past, but they are telling real-life stories.

"If inferior in power or intelligence to ourselves, so that we have the sense of looking down on a scene of bondage, frustration, or absurdity, the hero belongs to the ironic mode" (Frye 34). Linden was sinister and narrow, he blames Bazil for the ruin of his family and the death of his mother, but he does not dare to challenge him, so he attacks young women and children. Linda is born deformed and has an ugly image. The action power of the characters appears to be lower than ordinary people.

\section{CONCLUSION}

The archetypes of ancient Indian myths and legends can be seen everywhere in Erdich's works. From Tracks to The Round House, Erdich's portrayal of the image of the twins has gradually shifted from myth and legend to reality. The replacement and rewriting of the Myth of the Matchikweis - Oshkikwe sisters successfully move the background of the story to the modern reserve. From the legendary Fleur and Pauline, the tribal heroes Lulu and Mary, the ordinary townsfolk Rozin and Kelly to the less capable Linden and Linda, Erdrich makes the transition from mythic to legendary to realistic, taking the mythical "Matchikweis- Oshkikwe sisters as an archetype.

The use of mythology helps to build more complex and multiple relationships between characters, making the unexpected scenario more interesting and more readable. The sharp contrast between good and evil, beauty and ugliness, conveys the philosophy of life - prudence rather than crudity, kindness rather than cruelty.

The novels extend the role of the myth of the world warning, full of wisdom in dealing with the 
world. Erdrich takes on the responsibility of a storyteller, conveying positive values. At the same time, she made use of the Chippewa myth to link traditional culture with modern background and created her own legends. She realized the influence and appeal of the myth, and woven the novel and myth together, which aroused the interest of the readers with the background of Indian culture, and also let more non-Indian readers know about Indian culture. The precious heritage of national culture still exudes infinite charm, and the inspiration drawn from the primitive myth helps Erdrich to shape the twin or twinlike characters with various personalities.

\section{References}

[1] David Michael Jones\& Brain Leigh Molyneaux, American Mythology. Yu Shiyan, Trans. Guangzhou: New Century Publishing House, 2011.

[2] Shuxian Ye. Myth - Prototype Criticism. Xi 'an: Shaanxi Normal University Press, 2012.

[3] Paula Gunn Allen. Grandmothers of the Light: A Medicine Woman's Sourcebook. Boston: Beacon Press, 1991.

[4] Victor Barnouw. Wisconsin Chippewa Myths and Tales: and Their Relation to Chippewa Life. Madison: The University of Wisconsin Press, 1977.

[5] Louise Erdrich. Love Medicine. New York: Harper Perennial, 1993.

[6] Louise Erdrich. Tracks. New York: Harper Perennial, 1988.

[7] Louise Erdrich. The Antelope Wife. New York: Harper Perennial, 1998.

[8] Louise Erdrich. The Round House. New York: Harper Perennial, 2012.

[9] Northrop Frye. Anatomy of Criticism. Princeton: Princeton University Press, 1957.

[10] Connie A. Jacob. The Novels of Louise Erdrich: Stories of Her People. New York: Peter Lang, 2001.

[11] Kristan Sarve-Gorham. Power Lines: The Motif of Twins and the Medicine Women of "Tracks" and "Love Medicine". The Bucknell Review, 1995, 39 (1): 167-190.

[12] Juliana de Nooy. Twins in Contemporary Literature and Culture Look Twice. New York: Palgrave Macmillan, 2005. 